\title{
Disentangling habitat use by frugivorous birds: Constant interactive effects of forest cover and fruit availability
}

\author{
Daniel Martínez*, Daniel García \\ Departamento de Biología de Organismos y Sistemas, Universidad de Oviedo, and Unidad Mixta de Investigación \\ en Biodiversidad (CSIC-UO-PA), Oviedo 33071, Asturias, Spain
}

Received 9 September 2014; received in revised form 22 April 2015; accepted 30 April 2015

Available online 11 May 2015

\begin{abstract}
Frugivorous animals contribute to forest regeneration, but the provision of this ecosystem service is spatially filtered by the environmental factors limiting frugivore habitat use. Understanding how this filter acts in real-world landscapes is crucial for better predicting how habitat degradation impacts on seed dispersal services. Fruits and forest cover are main determinants of habitat use by frugivorous birds. The degree of spatial segregation between these habitat features would be expected to determine a trade-off for frugivores between finding food and being safe. Nevertheless, little is known about how such a trade-off may finally affect frugivore habitat use. We studied frugivorous bird habitat use in a landscape representing a gradient of forest loss and fragmentation in the Cantabrian Range (N Spain). For four years we evaluated the spatial patterns of the abundances of frugivorous birds, fruits, and forest cover. Both fruits and forest cover influenced bird habitat use in each year. However, we also found a consistent across-years interaction between the effects of forest cover and fruits. In each study year fruit tracking by frugivores increased in landscape sectors presenting sparce forest cover and vice versa, but that intense search for food or shelter weakened in those areas with dense forest cover and abundant fruits respectively. The simultaneous consideration of the different environmental factors limiting frugivore habitat use revealed long-term, complex landscape effects, which are expected to cascade into fine-grained variability of the spatial patterns of seed rain.
\end{abstract}

\section{Zusammenfassung}

Frugivore tragen zur Regeneration von Wäldern bei, aber diese Ökosytemleistung wird räumlich gefiltert durch Umweltfaktoren, die die Habitatnutzung der Frugivoren begrenzen. Zu verstehen, wie diese Filter in realen Landschaften funktionieren, ist essentiell für bessere Vorhersagen, wie die Verschlechterung von Lebensräumen Samenausbreitungsdienstleistungen beeinflusst. Früchte und Waldbedeckung sind die Hauptfaktoren für die Habitatnutzung von grugivoren Vögeln. Der Grad der räumlichen Trennung zwischen diesen Habitateigenschaften sollte bei den Frugivoren zu einem trade-off zwischen Nahrungssuche und Schutz vor Feinden führen. Aber wenig ist darüber bekannt, wie so ein trade-off die Habitatnutzung von Frugivoren beeinflussen könnte. Wir untersuchten die Habitatnutzung durch frugivore Vögel in einer Landschaft, die einen Gradienten von Waldverlust und Fragmentierung im Kantrabischen Gebirge (Nordspanien) repräsentiert. Vier Jahre lang überwachten wir die räumlichen Muster der Abundanz von frugivoren Vögeln, der Früchte und der Bewaldung. Sowohl Früchte als auch die Bewaldung beeinflussten die Habitatnutzung der Vögel in jedem Jahr. Wir fanden aber auch eine stete Interaktion zwischen dem Einfluss von Bewaldung und Früchten. In allen Untersuchungsjahren

${ }^{*}$ Corresponding author. Tel.: +34 985104830; fax: +34 985104777 .

E-mail address: danimartinezrodriguez@gmail.com (D. Martínez). 
nahm die Fruchtsuche durch Frugivore in Sektoren mit geringer Bewaldung zu, aber die intensive Suche nach Früchten oder Schutz schwächte sich in den Gebieten mit dichter Bewaldung bzw. reichem Früchteangebot ab. Die gleichzeitige Berücksichtigung der verschiedenen Umweltfaktoren, die die Habitatnutzung begrenzen, legte langfristige komplexe Landschaftseffekte offen, von denen wir meinen, dass sie sich in ein feinkörniges Muster des Samenschattens fortpflanzen.

(C) 2015 Gesellschaft für Ökologie. Published by Elsevier GmbH. All rights reserved.

Keywords: Habitat use; Habitat cover; Frugivorous birds; Fruit availability; Ecosystem function; Environmental filtering; N Spain

\section{Introduction}

Frugivorous animals, by contributing to seed dispersal and the concomitant plant regeneration, provide an important ecosystem service (Kremen et al. 2007; Farwig \& Berens 2012). They take seeds away from parent plants, decreasing density-dependent seed mortality (Hammond \& Brown 1998; Metz, Sousa, \& Valencia 2010), favoring gene flow (Hamrick, Murawski \& Nason 1993; Jordano \& Godoy 2002) and, when seeds are deposited in degraded areas, can promote recolonization and vegetation recovery (Wunderle 1997; Cavallero, Raffaele, \& Aizen 2013). However, this service is not delivered everywhere and it is characterized by important spatial heterogeneity, with the variability in frugivore distribution being the main underlying mechanism leading to that heterogeneity (Nathan \& Muller-Landau 2000; Côrtes \& Uriarte 2013). Thus, environmental factors that ultimately filter frugivore distribution, by conditioning the availability of their suitable habitat, will shape the spatial extent of the seed dispersal service (Alcántara, Rey, Valera, \& Sánchez-Lafuente 2000; Nathan \& Muller-Landau 2000; Cordeiro \& Howe 2003). In order to predict seed dispersal under potential scenarios of anthropogenic habitat degradation, such as forest clearing and fragmentation, a deeper understanding of the environmental filtering processes affecting frugivores in real-world landscapes is essential (Naeem \& Wright 2003; Kremen 2005; Tomimatsu et al. 2013). In the case of frugivorous birds, fruit abundance and woody plant cover have been frequently described as major drivers of habitat use (Herrera 1985; García, Zamora, \& Amico 2011; Blendinger et al. 2012). Birds are able to optimize their foraging by tracking fruit abundance through space and time, resulting in more intense use of fruit-rich patches (Herrera 1985; Rey 1995; Saracco, Collazo, \& Goom 2004; Blendinger et al. 2012; but see Tellería, Ramírez, \& Pérez-Tris 2008 for examples of non-optimal foraging). Protection against predators, often provided by dense woody plant cover, is also a fundamental habitat condition for frugivorous birds (but see Luck \& Daily 2003), who frequently avoid open areas where they are more vulnerable (Cardoso da Silva, Uhl, \& Murray 1996; Cordeiro \& Howe 2003; García et al. 2011). In many landscapes, both food and protection co-occur as fruits are concentrated in dense cover areas dominated by fleshy-fruited plants (e.g. García et al. 2011). However, in some habitats, especially those affected by anthropogenic alterations, frugivores must cope with spatially segregated food and protection (for example, in deforested areas with remnant fruiting trees, or in logged or plantation forest devoid of fruiting trees; Cleary, Boyle, Setyawati, Anggraeni, Loon, \& Menken 2007; Herrera \& García 2009). In these cases of uncoupling, frugivores should optimize their habitat use according to a trade-off between tracking fruits and staying within denser forest cover (Howe 1979; Fedriani \& Boulay 2006). However, despite its potential importance for frugivore habitat use, explicit evaluation of this sort of trade-off is scarce (but see García et al. 2011 for a scale-dependent approach). Due to interactive effects mediated by the optimization behavior of frugivores, a lower weighting of food or protection on influencing habitat use would be expected when the other factor, respectively, is widely available (e.g. frugivores would be less reluctant to visit risky sites in those areas still providing many fruits; García, Martínez, Herrera, \& Morales 2013). As the availability and distribution of fruits may change strongly between years, even in the same landscape (e.g. Herrera 1998; García et al. 2013), some kind of temporal inconsistency would be expected in the emerging trade-offs.

In this study, we focus on how main environmental filters shaped habitat use of frugivorous birds in a fragmented landscape of the Cantabrian Range. Previous studies in the same system have described seed rain patterns and their variability between years and through the landscape (Herrera, Morales, \& García 2011; García et al. 2013; García \& Martínez 2012; Martínez \& García 2014). Nevertheless, we still lack a proper understanding of the ecological mechanisms (i.e. habitat use of frugivorous birds) underlying seed dispersal patterns. Here, we evaluated, during four consecutive years, how habitat cover and food availability simultaneously affected the habitat use of frugivorous birds in this study system. We were especially interested in ascertaining if there was a trade-off between the influences of these two environmental features, and whether this trade-off showed temporal variability. For this purpose, we related the spatial patterns of bird abundance to those of forest cover and fruit abundance. Specifically we sought to answer the following questions. (1) Which factor (fruit abundance vs. forest cover) most influenced the abundance of frugivorous birds? (2) Did the effect of each of these factors on bird abundance vary depending on small-scale abundance of the other one? and (3) Were the environmental effects on the abundance of frugivorous birds consistent across years? 


\section{Materials and methods}

\section{Study system}

Our study system was the mid-elevation temperate secondary forest of the Cantabrian mountain range (Northern Spain). This is a common but low-cover habitat (García et al. 2013) occurring as fringe patches adjacent to mature stands (mainly composed by beech Fagus sylvatica), and as variable-sized fragments embedded in a matrix of stony pastures and heathland (Erica spp., Ulex europaeus). Secondary forest is dominated by the fleshy-fruited trees hawthorn Crataegus monogyna, holly Ilex aquifolium, yew Taxus baccata, rowan Sorbus aucuparia and whitebeam Sorbus aria, which account for more than $70 \%$ of tree cover. Fleshy fruits of these species are sugar-rich red berry-like fruits (arilated seed in yew), 10-14 mm in diameter, and contain 1-5 seeds (5-9 mm). All species show an overlapping ripening period in early autumn, with their fruits staying on the tree until mid-winter. These fruits are mainly consumed by thrushes: blackbird Turdus merula, fieldfare Turdus pilaris, mistle thrush Turdus viscivorus, redwing Turdus iliacus, song thrush Turdus philomelos, and ring-ouzel Turdus torquatus (Martínez, García, \& Obeso 2008). T. pilaris, T. iliacus and T. torquatus are over-wintering species in Northern Spain, whereas T. merula, T. viscivorus and T. philomelos are species with resident populations that are joined by individual overwintering migrants. These species show territoriality and a mostly insectivorous diet through spring and summer, but they show aggregative and flocking behavior during autumn and winter, when they rely mostly on fleshy fruits for food (Snow \& Snow 1988). All thrush species feed upon all different tree fruits present in the secondary forest (Martínez et al. 2008; García et al. 2013). They swallow the entire fruit, sometimes regurgitating them but more frequently expelling the intact seeds in their feces, thereby acting as legitimate seed dispersers (Jordano 2000). Mammals contribute to tree seed dispersal, although to a considerably lesser extent than thrushes (Martínez et al. 2008; Peredo, Martínez, RodríguezPérez, \& García 2013).

\section{Study site}

The study site is located in the Sierra de Peña Mayor (1000 m a.s.l.; $\quad 43^{\circ} 17^{\prime} 59^{\prime \prime} \mathrm{N}, \quad 5^{\circ} 20^{\prime} 29^{\prime \prime} \mathrm{W}$ Asturias, Northwest Spain). At this site, secondary forest appears highly fragmented and intermingled with mature forests, meadows, heathlands and limestone outcrops. This landscape configuration results from historical deforestation for cattle grazing and, to a lesser extent, from natural fragmentation (rocky outcrops). Fleshy-fruited tree species are accompanied by hazel Corylus avellana and a small number of individuals of other non fleshy-fruited trees (F. sylvatica and ash Fraxinus excelsior). The study was conducted within a $400 \times 440 \mathrm{~m}$ rectangular plot (Appendix

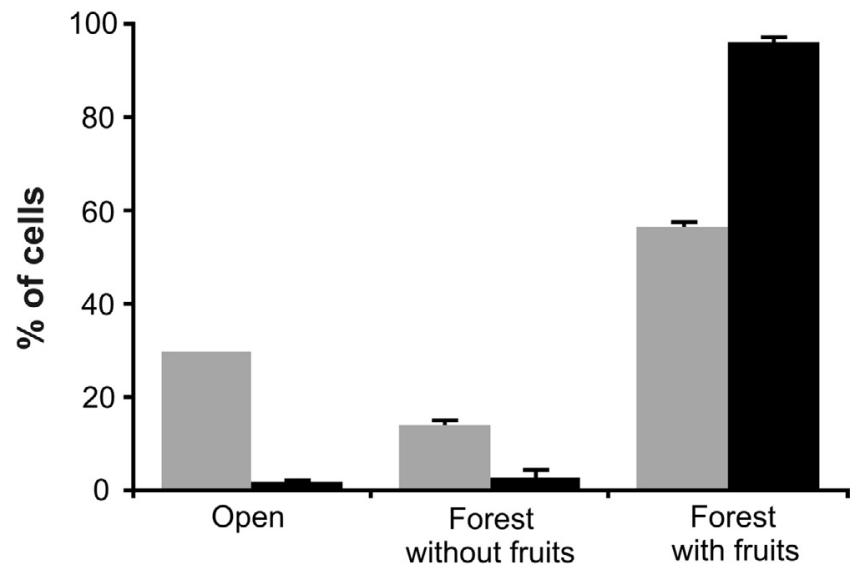

Habitat structure

Fig. 1. Distribution of cells in which bird presence was recorded (black) according to their habitat characteristics (Open: with no forest cover) compared with that of all cells in the plot (gray). Mean values of all four study years $( \pm \mathrm{SE})$ are shown.

A: Fig. 1) where secondary forest cover (no mature stands are found within the plot) varies from dense stands to scattered trees isolated within the non-forested matrix stands (García et al. 2013). Thus the plot represents a wide range of different forest cover and, potentially, fruit production contexts. For the better management of spatial information, the plot was subdivided into $44020 \times 20 \mathrm{~m}$ cells. Previous studies have proven that the size of the study plot and cells are appropriate in terms of extent and grain, respectively, for studying variability in habitat cover and fruit abundance, with cell size representing a relevant scale for bird habitat use and heterogeneity in seed rain patterns (García \& Martínez 2012; García et al. 2013; Martínez \& García 2014). The study was carried out over four consecutive years: the autumn-winter seasons of 2008-09, 2009-10, 2010-11 and 2011-12 (hereafter, respectively 2008, 2009, 2010 and 2011).

\section{Forest cover and fruit counts}

We developed a Geographic Information System of the study plot (GIS, ArcGIS 9.3) based on a recent (2009) 1:5000scale orthophotograph. We generated a layer with precise geo-referenced information about the boundaries of the plot, including the grid of $44020 \times 20 \mathrm{~m}$ cells (Appendix A: Fig. 1). Another GIS layer was generated representing the extent and location of forest cover by carefully digitizing this information from the orthophotograph. The forest cover layer included the canopy projection of all trees $(\mathrm{DBH}>10 \mathrm{~cm}$, height $>1.5 \mathrm{~m}$ ), verifying doubtful cases afterwards in the field.

At the beginning of the 2008 sampling season, we surveyed the entire plot, mapping all standing trees within the study plot and identifying them at the species level. Based on this 
census, each year, we visually estimated the number of standing fruits on each fruiting tree by using a semi-logarithmic scale (Fruit Abundance Index, FAI: $1=1-10$ fruits; $2=11-100 ; 3=101-1000 ; 4=1001-10000$; $5>10,000)$. In the system and site studied, fruiting of all individuals of the different study species is synchronous and ripening occurs within 1-2 months (although fruits remain attached to trees for a further 1-3 months). Thus, we considered that a single sampling of fruit abundance at the beginning of the season (October) provided an appropriate estimate of the spatial arrangement of fruit resources (García et al. 2013).

Then, by using the GIS, we calculated the area covered by forest cover $\left(\mathrm{m}^{2}\right)$ and fruit abundance per cell. Fruit abundance was obtained as the sum of the crop sizes of all the fruiting trees in a cell. The crop sizes of the fruiting trees were extrapolated from FAI ranks, taking into account the fit between the actual crop size of a sub-sample of trees and FAI, by following an allometric equation (actual crop size $=1.765^{1.924 \times F A I} ; R^{2}=0.80 ; N=136$; Herrera et al. 2011). For detailed information on this procedure see Appendix A. Additionally, as a qualitative measure of habitat structure, each year we classified plot cells into three different categories according to their availability of forest cover and fruits: open (cells with no forest cover), forest without fruits (cells presenting forest cover but where no fruits were produced), and forest with fruits (cells presenting both forest cover and fruits).

\section{Bird observations}

We performed bird observations within the study plot to estimate the abundance and spatial distribution of frugivorous birds (Turdus spp.) in the different cells during the fruiting season each year. Observations of thrushes were made from vantage positions covering large high-visibility areas, and from positions within the forest for more reduced areas where bird detectability from vantage positions was lower (Appendix A: Fig. 1). Observations were made with the time being balanced between the various stations throughout each season. We assigned each bird sighting to the cell of the study plot where it happened. The abundance of birds per cell was calculated as the cumulative number of birds detected in each cell during the season divided by the total observation time for each cell, calculating the number of birds per $10 \mathrm{~h}$ of observation. Bird abundance resulting from these censuses lead to an estimation of total frugivore activity throughout the season for the different cells of the study plot (García \& Martínez 2012; García et al. 2013). For detailed information on the methodology of bird censuses see Appendix A (see also García \& Martínez 2012; García et al. 2013).

\section{Statistical analyses}

Between-year variations in fruit abundance and in the abundance of birds were tested by means of Generalized
Linear Models (GLMs) with a quasi-Poisson error distribution and $\log$ link function.

To assess frugivore habitat selection we compared the actual distribution of plot cells according to their forest structure with that of cells in the same categories where bird presence was detected. Independent comparisons were made for each year by means of Pearson's Chi ${ }^{2}$ test.

To assess the influence of forest cover and fruit abundance on bird abundance we used Zero-inflated GLMs with Poisson error distribution and $\log$ link function building an independent model for each study year. As predictor variables, all models included forest cover and fruit abundance, together with the interaction term forest cover $\times$ fruit abundance, and bird abundance (no. of birds per $10 \mathrm{~h}$ of observation) as response variable. Correlation between the predictor variables was $r<0.7$ (Pearson's coefficient) in all models (see Appendix B).

Due to configuration of the sampling framework (adjacent cells of the study plot), the estimation of the effects of forest cover and fruit abundance on bird abundance may have been affected by the potential spatial autocorrelation in the response variable (Keitt, Bjornstad, Nixon, \& CitronPousty 2002). Thus, to check for the consequences of spatial constraints in the previous Zero-Inflated models, we fitted simultaneous autoregressive models (SAR; Keitt et al. 2002; see Appendix C).

When significant interaction terms occurred in the Zeroinflated GLMs, a posteriori analyses were performed to evaluate the effect of a given predictor (forest cover or fruit abundance) on the response variable at different levels of the other predictor. To do that, we performed linear regressions confronting the values of the response variable predicted by the original whole model with the partial residuals of each predictor (i.e. the residuals of one predictor against the other), at different levels of the other predictor (Quinn \& Keough 2002; Lamina, Sturm, Kollerits, \& Kronenberg 2012). We differentiated two levels: low, with values from 0 to the respective mean of the distribution; and high, with values above the mean of the distribution. Statistical comparison between regression coefficients were made following Zar (1996). All analyses were performed using R 2.15 (R Core Team 2013), with pscl package for Zero-inflated GLMs.

\section{Results and discussion}

\section{General results}

Fruit abundance varied between years (GLM: $F=1904$, $p<0.0001, D F=1756$ ), with lower fruit production in 2008 $\left(10.25 \pm 1.14\right.$ fruits per $\mathrm{m}^{2}$ per cell) than in subsequent years (always >17 fruits per square meter per cell; Appendix D: Fig. 1A). Bird abundance also varied between years (GLM: $F=44.02, p<0.0001, D F=1756)$. The lowest bird abundance was observed during $2010(2.25 \pm 0.39$ birds per $10 \mathrm{~h}$ per cell) and the maximum in 2011 (4.37 \pm 0.77$)$, while 
2008 and 2009 showed intermediate values $(2.67 \pm 0.24$ and $3.96 \pm 0.47$, respectively; Appendix D: Fig. 1B).

Presence of birds was distributed unequally between cells with different forest structure (Chi ${ }^{2}$ test: $F>38, d . f .=2$ and $p<0.001$ for all years; Fig. 1). Birds occurred more frequently than expected in those cells with both forest cover and fruits. Conversely, they significantly avoided open cells and, to a lesser extent, cells with forest cover but no fruits. GLM models showed that forest cover and fruit abundance influenced bird abundance in all years, with consistently stronger effects for forest cover than for fruit abundance (Table 1). Taken as a whole, these results suggest that birds actively selected their habitat, but also that they used habitat more in line with safety considerations than with food availability (see also Brown, 2000). A higher relevance of forest cover for habitat use by thrushes would be also expected if these birds perceived dense forest as a first cue for looking for fleshy-fruited trees. Nonetheless, our results also suggest that birds tracked fruit availability across the studied landscape (Table 1), as suggested for other frugivorous birds in temperate and tropical habitats (e.g. Lehouck, Spanhove, Vangestel, Cordeiro, \& Lens 2009; García, Zamora, \& Amico 2010; Blendinger et al. 2012). In our study system, the flocking behavior of most thrush species, together with their almost exclusively fruitbased diet (Guitián et al. 2000; Martínez et al. 2008), are traits that would promote active fruit resource tracking.

\section{Interaction between the effects of forest cover and fruit abundance}

GLM models also revealed a significant interaction between the effects of forest cover and fruit abundance in each year (Table 1). Our four-year data set suggests that the effects of these environmental features varied in the landscape, as the limitations imposed by either feature on frugivore habitat use depended on the magnitude of the other (Tables 1 and 2). As evidenced by partial lineal regressions, the positive effects of forest cover on bird abundance differed between low and high fruit abundance levels (Table 2; differences between slopes: $t>1.96, p<0.05$ for all the cases). That is to say, frugivore dependence on forest cover increased in those landscape sectors with scarce fruits, but weakened when fruits were abundant and widespread. This pattern was conceivably related to a trade-off in bird behavioral decisions, with birds being mostly driven by the search for protection when fruits are scarce, but overcoming their reluctance to visit low cover areas when these provide many fruits, as happens when they contain remnant trees with large crop sizes (Herrera \& García 2009). The effects of fruit availability on bird abundance also differed across levels of forest cover. Birds used fruit-rich patches more frequently when forest cover was low, but, unexpectedly, they avoided fruit-rich sites in highly forested landscape sectors in three out of four study years (Table 2; differences between slopes: $t>1.96, p<0.05$ for all the cases). Such a negative trend could be explained by strong

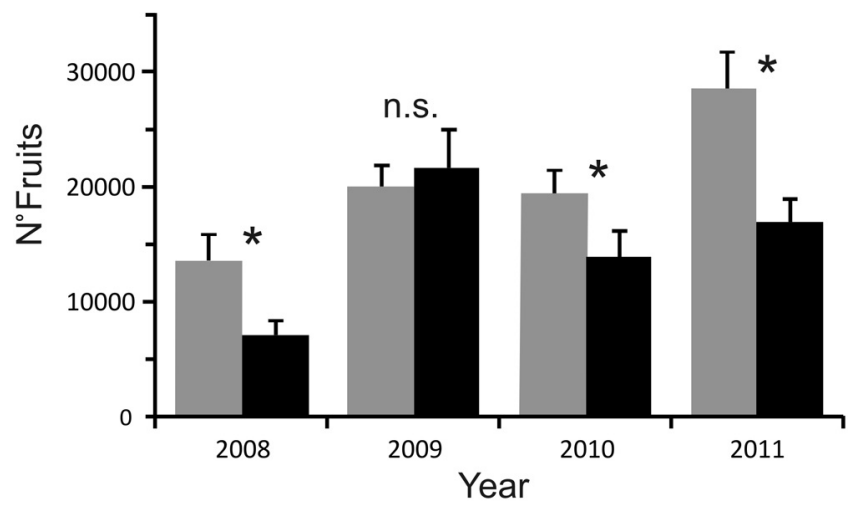

Fig. 2. Mean fruit abundance per cell $( \pm \mathrm{SE})$ in cells presenting big trees $(n=50$; black) and cells without big trees ( $n=54$, gray) but with comparatively similar forest cover ( $>50 \%)$. Differences in the number of fruits between types of cell have been highlighted (Wilcoxon test; ${ }^{*}: p \leq 0.05$; n.s.: $p>0.05$ ).

competition between birds in fruit-rich areas, but we consider this process unlikely to occur in our study system. Although some negative interactions (e.g. defense of fruiting trees by individual birds) occurred in the system studied (authors' personal observations, see also Snow \& Snow 1984), these were sporadic and occurred at a very fine spatial scale (i.e. between birds foraging in the same tree). In fact, the relative abundances of the different thrush species are frequently correlated in our study system (García \& Martínez 2012), suggesting interspecific facilitation rather than competition at the population level (see also Saracco et al. 2004).

\section{Environmental effects after excluding the influence of big trees}

In search of other plausible explanations for this negative trend we did a post hoc evaluation of the characteristics of sites with dense forest cover but few fruits. This evaluation revealed a differential feature: the occurrence of big trees whose tops outgrew the average forest canopy (see Appendix A for big tree classification procedure). These tall trees provided much cover (forest cover was $>50 \%$ in cells presenting a big tree) although, in most years, their presence was associated with a decrease in fruit abundance (as they were species without fleshy fruits, such as beech or ash, or individuals without fruits, such as male yew trees) in the plot cells where they occurred (see Fig. 2). Thrushes frequently alighted on these big trees (authors' unpublished data), possibly using them as resting sites or watchtowers for predator vigilance (see García 2001). In order to control how the occurrence of big trees affected the interactive effects of forest cover and fruit abundance on the abundance of frugivorous birds, we repeated the previous models excluding those cells presenting big trees. These analyses showed that forest cover, fruit abundance, and the interaction between them, maintained their previously found effects on birds' habitat use. Moreover, Spatial Autoregressive (SAR) models 
Table 1. Effects of forest cover and fruit abundance on the abundance of frugivorous birds. Independent Zero-Inflated GLMs were performed for each study year. Maximum likelihood estimates, their standard errors, the values of the $z$ statistic and $p$ values are shown. McFadden's $R^{2}$ value is shown for every model.

\begin{tabular}{|c|c|c|c|c|}
\hline & Estimate & Std. error & $z$ & $p$ \\
\hline \multicolumn{5}{|l|}{$2008\left(R^{2}=0.34\right)$} \\
\hline Intercept & 5.526 & 0.005 & 1071.5 & $<0.001$ \\
\hline Forest cover & 0.736 & 0.003 & 231.2 & $<0.001$ \\
\hline Fruit abundance & 0.109 & 0.007 & 16.2 & $<0.001$ \\
\hline Forest cover $\times$ fruit abundance & -0.116 & 0.004 & -26.4 & $<0.001$ \\
\hline \multicolumn{5}{|l|}{$2009\left(R^{2}=0.35\right)$} \\
\hline Intercept & 5.823 & 0.004 & 1382.5 & $<0.001$ \\
\hline Forest cover & 0.645 & 0.003 & 225.5 & $<0.001$ \\
\hline Fruit abundance & 0.389 & 0.004 & 96.9 & $<0.001$ \\
\hline Forest cover $\times$ fruit abundance & -0.137 & 0.002 & -63.5 & $<0.001$ \\
\hline \multicolumn{5}{|l|}{$2010\left(R^{2}=0.27\right)$} \\
\hline Intercept & 5.209 & 0.006 & 856.2 & $<0.001$ \\
\hline Forest cover & 0.847 & 0.004 & 230.8 & $<0.001$ \\
\hline Fruit abundance & 0.268 & 0.005 & 56.6 & $<0.001$ \\
\hline Forest cover $\times$ fruit abundance & -0.176 & 0.003 & -57.8 & $<0.001$ \\
\hline \multicolumn{5}{|l|}{$2011\left(R^{2}=0.33\right)$} \\
\hline Intercept & 5.734 & 0.004 & 1291.7 & $<0.001$ \\
\hline Forest cover & 1.026 & 0.003 & 372.1 & $<0.001$ \\
\hline Fruit abundance & 0.274 & 0.004 & 68.9 & $<0.001$ \\
\hline Forest cover $\times$ fruit abundance & -0.235 & 0.002 & -103.7 & $<0.001$ \\
\hline
\end{tabular}

Table 2. Independent effects of one given environmental predictor (either forest cover or fruit abundance) at different values of the other predictor on the abundance of frugivorous birds (values predicted by GLMs in Table 1$)$ considering all sampling cells $(N=440)$. $\beta$ values $( \pm \mathrm{SE})$ of the linear regressions between partial residuals of each predictor and bird abundance, at low and high levels of the other predictor, are shown for each study year ( $p<0.05$ in all cases). $N=138$ for high forest cover cells and $N=302$ for low forest cover cells in all cases. High fruit abundance cells ranged from $N=116$ to 130 and low fruit abundance cells from $N=310$ to 324 depending on the year.

\begin{tabular}{llrlrr}
\hline Year & \multicolumn{2}{l}{ Forest cover } & & \multicolumn{2}{l}{ Fruit abundance } \\
\cline { 2 - 3 } & Low fruit abundance & High fruit abundance & & Low forest cover & High forest cover \\
\hline 2008 & $17.33 \pm 0.24$ & $13.86 \pm 0.69$ & & $2.07 \pm 0.17$ & $-3.91 \pm 0.88$ \\
2009 & $19.01 \pm 0.27$ & $5.31 \pm 2.36$ & & $8.40 \pm 0.39$ & $-3.61 \pm 0.89$ \\
2010 & $16.89 \pm 0.25$ & $11.28 \pm 0.83$ & $3.42 \pm 0.11$ & $-12.88 \pm 1.96$ \\
2011 & $44.75 \pm 0.90$ & $30.47 \pm 1.99$ & & $5.69 \pm 0.42$ & \\
\hline
\end{tabular}

evidenced that these effects also occurred after accounting for potential spatial autocorrelation constraints (see, Appendix C: Tables 2 and 3). We still found forest cover to be the main factor affecting the birds' habitat use, with stronger effects in poor-fruit areas (Fig. 3, Table 3; Appendix C: Table 1). The effects of fruit availability on the abundance of frugivorous birds also continued to be stronger, and positive, at low cover levels, but positive or null at high cover levels

Table 3. Independent effects of one given environmental predictor (either forest cover or fruit abundance) at different values of the other predictor on the abundance of frugivorous birds (values predicted by GLMs in Appendix C: Table 1) considering sampling cells devoid of big trees $(N=388)$. $\beta$ values $( \pm$ SE) of the linear regressions between partial residuals of each predictor and bird abundance, at low and high levels of the other predictor, are shown for each study year (n.s.: $p>0.05, p \leq 0.05$ in all other cases). $N=88$ for high forest cover cells and $N=300$ for low forest cover cells in all cases. High fruit abundance cells ranged from $N=79$ to 99 and low fruit abundance cells from $N=289$ to 309 depending on the year.

\begin{tabular}{lccccc}
\hline Year & \multicolumn{2}{l}{ Forest cover } & & \multicolumn{2}{l}{ Fruit abundance } \\
\cline { 2 - 3 } & Low fruit abundance & High fruit abundance & & Low forest cover & High forest cover \\
\hline 2008 & $7.38 \pm 0.08$ & $5.96 \pm 0.75$ & $1.77 \pm 0.17$ & $1.11 \pm 0.63$ \\
2009 & $12.49 \pm 0.20$ & $4.95 \pm 0.27$ & $10.25 \pm 0.58$ & $2.75 \pm 1.11$ & n.s. \\
2010 & $3.49 \pm 0.05$ & $0.97 \pm 0.18$ & $2.18 \pm 0.07$ & n.s. \\
2011 & $15.68 \pm 0.03$ & $8.37 \pm 1.31$ & $4.94 \pm 0.37$ & \\
\hline
\end{tabular}



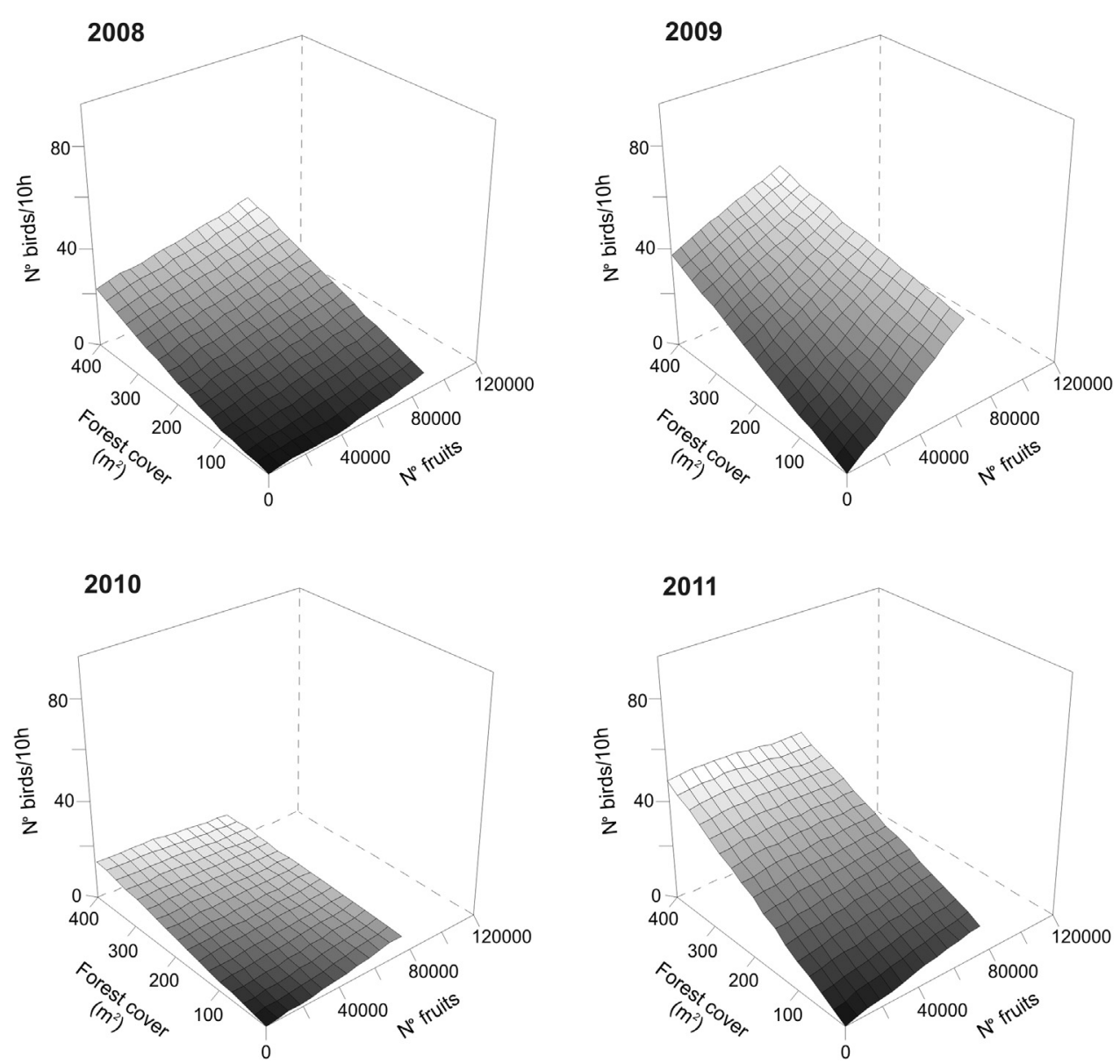

Fig. 3. Expected values of bird abundance for combinations of different values of forest cover and fruit abundance for different study years. Variations are highlighted in shades of gray, with darker tones representing lower values. Trend surfaces were obtained by interpolation of the predicted values extracted from the Zero-Inflated GLMs (cells with big trees excluded).

(Fig. 3, Table 3; differences between slopes: $t>1.96, p<0.05$ for all the cases). In sum, the dilution of the effects of fruit availability on the abundance of frugivorous birds along the gradient of forest cover also suggests that frugivores optimize their habitat use at a small scale (Howe 1979; Brown 2000; Mayor, Scheneider, Schaefer, \& Mahoney 2009). Namely, frugivores would strongly track fruit resources if not sufficiently protected, but relax the search for fruits in low-risk areas (as suggested by Brown, 2000). This pattern of the flat numerical response of birds to fruit abundance could equally be interpreted as the result of a process of frugivore satiation (Hampe 2008), as high cover areas usually provide the densest fruiting patches across the landscape. The fact that birds were unresponsive to fruit abundance in these high cover areas, in those years with the highest total fruit production (2010 and 2011; Fig. 3, Table 3; Appendix D: Fig. 1), would support this rationale.

Our four-year data series suggests that the complex landscape effects on frugivore habitat use are consistent across time, overcoming the limitations of previous, short-term studies based on simplified views of landscape variability (e.g. García et al. 2011). Here, a similar interaction between the influence of forest cover and fruits on frugivorous birds appeared every year, suggesting that the same sort of tradeoff between shelter and food search drove bird foraging decisions. Such a consistent pattern of interactive effects occurred even when the abundance and the spatial distribution of fruits varied strongly between years over the forest cover (Appendix D: Fig. 1; see García et al. 2013; Martínez \& García 2014 for variations in fruit spatial distribution). Nevertheless, this temporal dynamism in the large-scale distribution of fruits would probably be affecting the relative strength of the respective influences of habitat cover and food availability, which actually varied across years (Table 3; Appendix C: Table 1). These variations in strength would agree with the temporal variability highlighted in previous studies in the same system, affecting other aspects of these plant-frugivore interactions, from fruit consumption to seed dispersal (Herrera et al. 2011; García et al. 2013; Martínez \& García 2014; Martínez et al. 2014).

\section{Conclusions}

In this study, we fine-tune the current understanding of environmental filtering in the habitat use of frugivorous birds. 
Our results evidence that simultaneously considering forest cover and fruit availability reveals complex landscape effects on frugivore activity. Its high temporal consistency would lead this environmental filtering to leave a significant imprint on the ecosystem services that animals provide (Kremen 2005; Kremen \& Ostfeld 2005). Specifically, stronger fruit tracking in low forest cover areas would be the mechanism explaining that small forest patches and isolated trees presenting high fruit crops receive a magnitude of seed deposition higher than expected (e.g. García et al. 2010). Further studies should address whether the temporally consistent interactive effects of habitat cover and resource availability evidenced here are generalizable to more complex plantfrugivore systems (e.g. tropical forest; Luck \& Daily 2003; Lehouck et al. 2009; Saracco et al. 2004), but also to other ecosystem services derived from the trophic activity of animals (e.g. pollination, pest control; Kremen et al. 2007) in real-world landscapes.

\section{Acknowledgements}

We thank C. Guardado and J. Rodríguez for technical support and R. Lendrum for linguistic advice. We also thank C. Guardado and A. Suarez-Esteban for their suggestions on the manuscript. Field work was conducted with the permission of the Wildlife Service of Asturias. Funding was provided by the Spanish Ministry of Science and European Social Fund (FPI grant to DM and CGL2008-01275 and CGL2011-28430 grants to DG).

\section{Appendix A. Supplementary data}

Supplementary data associated with this article can be found, in the online version, at http://dx.doi.org/10.1016/ j.baae.2015.04.012.

\section{References}

Alcántara, J. M., Rey, A., Valera, F., \& Sánchez-Lafuente, A. M. (2000). Factors shaping the seedfall pattern of a bird-dispersed plant. Ecology, 81, 1937-1950.

Blendinger, P. G., Ruggera, R. A., Núñez Montellano, M. G., Macchi, L., Zelaya, P. V., Álvarez, M. E., et al. (2012). Fine-tuning the fruit tracking hypothesis: Spatiotemporal links between fruits availability and fruit consumption by birds in Andean mountain forest. Journal of Animal Ecology, 81, 1298-1310.

Brown, J. S. (2000). Foraging ecology of animals in response to heterogeneous environments. In J. Hutchings, \& A. Stewart (Eds.), The ecological consequences of environmental heterogeneity (pp. 181-215). Oxford: Blackwell Scientific.

Cardoso da Silva, J. M. C., Uhl, C., \& Murray, G. (1996). Plant succession, landscapes management, and the ecology of frugivorous birds in abandoned Amazonian pastures. Conservation Biology, 10, 491-503.
Cavallero, L., Raffaele, E., \& Aizen, M. A. (2013). Birds as mediators of passive restoration during early post-fire recovery. Biological Conservation, 158, 342-350.

Cleary, D. F., Boyle, T. J., Setyawati, T., Anggraeni, C. D., Loon, E. E. V., \& Menken, S. B. (2007). Bird species and traits associated with logged and unlogged forest in Borneo. Ecological Applications, 17, 1184-1197.

Cordeiro, N. J., \& Howe, H. F. (2003). Forest fragmentation severs mutualism between seed dispersers and an endemic African tree. Proceedings of the National Academy of Science, 100, 14052-14056.

Côrtes, M. C., \& Uriarte, M. (2013). Integrating frugivory and animal movement: A review of the evidence and implications for scaling seed dispersal. Biological Reviews, 88, 255-272.

Farwig, N., \& Berens, D. G. (2012). Imagine a world without seed dispersers: A review of threats, consequences and future directions. Basic and Applied Ecology, 13, 109-115.

Fedriani, J. M., \& Boulay, R. (2006). Foraging by fearful frugivores: Combined effects of fruit ripening and predation risk. Functional Ecology, 20, 1070-1079.

García, D. (2001). Effects of seed dispersal on Juniperus communis recruitment on a Mediterranean mountain. Journal of Vegetation Science, 12, 839-848.

García, D., \& Martínez, D. (2012). Species richness matters for the quality of ecosystem services: A test using seed dispersal by frugivorous birds. Proceedings of the Royal Society B: Biological Sciences, 279, 3106-3113.

García, D., Martínez, D., Herrera, J. M., \& Morales, J. M. (2013). Functional heterogeneity in a plant-frugivore assemblage enhances seed dispersal resilience to habitat loss. Ecography, 36, 197-208.

García, D., Zamora, R., \& Amico, G. C. (2010). Birds as suppliers of seed dispersal in températe ecosystems: Conservation guidelines from real-world landscapes. Conservation Biology, 24, 1070-1079.

García, D., Zamora, R., \& Amico, G. C. (2011). The spatial scale of plant-animal interactions: Effects of resource availability and habitat structure. Ecological Monographs, 81, 103-121.

Guitián, J., Guitián, P., Munilla, I., Guitián, J., Beremejo, T., Larrinaga, A. R., et al. (2000). Zorzales, espinos y serbales. Un estudio sobre el consumo de frutos silvestres de las aves migratorias en la costa occidental europea. Universidade de Santiago de Compostela.

Hammond, D. S., \& Brown, V. K. (1998). Disturbance, phenology and life-history characteristics: Factors influencing distance/density-dependent attack on tropical seeds and seedlings. In D. M. Newbery, H. H. T. Prins, \& N. D. Brown (Eds.), Dynamics of tropical communities (pp. 51-78). Oxford: Blackwell Science.

Hampe, A. (2008). Fruit tracking, frugivore satiation, and their consequences for seed dispersal. Oecologia, 156, 137-145.

Hamrick, J. L., Murawski, D. A., \& Nason, J. D. (1993). The influence of seed dispersal mechanisms on the genetic structure of tropical tree populations. Vegetatio, 107, 281-297.

Herrera, C. M. (1985). Habitat-consumer interactions in frugivorous birds. In L. M. Cody (Ed.), Habitat selection in birds (pp. 341-365). London: Academic Press Inc.

Herrera, C. M. (1998). Long-term dynamics of Mediterranean frugivorous birds and fleshy fruits: A 12-year study. Ecological Monographs, 68, 511-538. 
Herrera, J. M., \& García, D. (2009). Role of remnant trees in seed dispersal through the matrix: being alone is not always so sad. Biological Conservation, 143, 149-158.

Herrera, J. M., Morales, J. M., \& García, D. (2011). Differential effects of fruit availability and habitat cover for frugivoremediated seed dispersal in a heterogeneous landscape. Journal of Ecology, 99, 1100-1107.

Howe, H. F. (1979). Fear and frugivory. The American Naturalist, 114, 925-931.

Jordano, P. (2000). Fruits and frugivory. In M. Fener (Ed.), Seeds: The ecology of regeneration in plant communities (pp. 125-166). Wallingford: CABI Publ.

Jordano, P., \& Godoy, J. A. (2002). Frugivore-generated seed shadows: A landscape view of demographic and genetic effects. In D. J. Levey, W. R. Silva, \& M. Galetti (Eds.), Seed dispersal and frugivory: Ecology, evolution and conservation (pp. 305-321). Wallingford: CABI Publ.

Keitt, T. H., Bjornstad, O. N., Nixon, P. M., \& Citron-Pousty, S. (2002). Accounting for the spatial pattern when modeling organism-environment relationships. Ecography, 25, 616-625.

Kremen, C. (2005). Managing ecosystem services: What do we need to know about their ecology. Ecology Letters, 8, 468-479.

Kremen, C., \& Ostfeld, R. S. (2005). A call to ecologist: Measuring, analyzing, and managing ecosystem services. Frontiers in Ecology and the Environment, 3, 540-548.

Kremen, C., Williams, N. M., Aizen, M. A., Gemmill-Herren, B., LeBuhn, G., Minckley, R., et al. (2007). Pollination and other ecosystem services produced by mobile organisms: A conceptual framework for the effects of land-use change. Ecology Letters, 10, 299-314.

Lamina, C., Sturm, G., Kollerits, B., \& Kronenberg, F. (2012). Visualizing interactions effects: A proposal for presentation and interpretation. Journal of Clinical Epidemiology, 65, 855-862.

Lehouck, V., Spanhove, T., Vangestel, C., Cordeiro, N. J., \& Lens, L. (2009). Does landscape structure affect resource tracking by avian frugivores in a fragmented Afrotropical forest? Ecography, 32, 789-799.

Luck, G. W., \& Daily, G. (2003). Tropical countryside bird assemblages: Richness, composition, and foraging differ by landscape context. Ecological Applications, 13, 235-247.

Martínez, D., \& García, D. (2014). Changes in the fruiting landscape relax restrictions on endozoochorous tree dispersal into deforested lands. Applied Vegetation Science, http://dx.doi.org/10.1111/avsc

Martínez, I., García, D., \& Obeso, J. R. (2008). Differential seed dispersal patterns generated by a common assemblage of vertebrate frugivores in three fleshy-fruited trees. Ecoscience, 15, 189-199.

Mayor, S. J., Scheneider, D. C., Schaefer, J. A., \& Mahoney, S. P. (2009). Habitat selection at multiple scales. Écoscience, 16, 238-247.

Metz, M. R., Sousa, W. P., \& Valencia, R. (2010). Widespread density-dependent seedling mortality promotes species coexistence in highly diverse Amazonian forest. Ecology, 91, 3675-3685.

Naeem, S., \& Wright, J. P. (2003). Disentangling biodiversity effects on ecosystem functioning: Deriving solutions to a seemingly insurmountable problem. Ecology Letters, 6, 567-579.

Nathan, R., \& Muller-Landau, H. (2000). Spatial patterns of seed rain, their determinants and consequences for recruitment. Trends in Ecology \& Evolution, 15, 278-285.

Peredo, A., Martínez, D., Rodríguez-Pérez, J., \& García, D. (2013). Mammalian seed dispersal in Cantabrian woodland pastures: Network structure and response to forest loss. Basic and Applied Ecology, 14, 378-386.

Quinn, G. P., \& Keough, M. J. (2002). Experimental design and data analysis for biologists. Cambridge: Cambridge University Press.

R Core Team. (2013). $R$ : A language and environment for statistical computing. Vienna: R Foundation for Statistical Computing. http://www.R-project.org/

Rey, P. (1995). Spatio-temporal variation in fruit and frugivorous abundance in olive orchards. Ecology, 76, 1625-1635.

Saracco, J. F., Collazo, J. A., \& Goom, M. J. (2004). How do frugivores track resources? Insights from spatial analyses of bird foraging in a tropical forest. Oecologia, 139, 235-245.

Snow, B., \& Snow, D. (1984). Long-term defense of fruit by Mistle Thrushes Turdus viscivorus. Ibis, 126, 39-49.

Snow, B., \& Snow, D. (1988). Birds and berries. Calton: T \& AD Poyser.

Tellería, J. L., Ramírez, A., \& Pérez-Tris, J. (2008). Fruit tracking between sites and years by birds in Mediterranean wintering grounds. Ecography, 31, 381-388.

Tomimatsu, H., Sasaky, T., Kurokawa, H., Bridle, J. R., Fontaine, C., Kitano, J., et al. (2013). Sustaining ecosystem functions in a changing world: A call for an integrated approach. Journal of Applied Ecology, 50, 1124-1130.

Wunderle, J. M. (1997). The role of animal seed dispersal in accelerating native forest regeneration on degraded tropical lands. Forest Ecology and Management, 99, 223-235.

Zar, J. H. (1996). Biostatistical analysis. New Jersey: Prentice Hall.

Available online at www.sciencedirect.com 